\title{
Social Integration and the Ala Loa: Reconsidering the Significance of Trails in Hawaiian Exchange
}

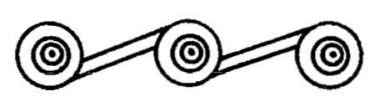

PETER R. MILLS

In November 2000, President Clinton designated a 175-mile section of coastal trail on Hawai'i's Big Island as a National Historic Trail, which has recently been dubbed the Ala Kahakai (trail by the sea). More traditional names for the same trail include Ala Loa (long trail), Ala Aupuni (government trail), and Alanui Aupuni (great government trail, the last two usually pertaining to the Hawaiian Monarchy's nineteenth-century improvements to the trail), and the "Old Government Beach Road." It is one of only a dozen National Historic Trails in the nation. However, a historical review entitled Trails, from Steppingstones to Kerbstones (Apple 1965), and a Final Environmental Impact Statement prepared for the National Historic Trail designation (National Park Service 1998), are the only broadly published studies of the trail system. Both of these studies rely heavily on historical documentation and include only scant archaeological data.

Prehistoric trail systems developed throughout the Hawaiian Islands, and as Patrick Kirch (1985:266) stated, they "form an important component of settlement landscapes, and their study provides important data on the linkages between individual communities." Archaeological evidence of trail systems has preserved best on the leeward sides of islands, such as the Ala Loa on Maui and on Hawai'i Island, yet the dating of prehistoric trail systems remains somewhat problematic due to the scarcity of items that can be directly dated on or under the trails themselves, and the fact that later use and modifications of trails often obscure evidence of earlier uses. Nevertheless, by examining nearby sites and features, general patterns of land use allow for reasonable inferences as to when trails began to be used. For the protohistoric and historical eras, there are often specific references to the construction and use of certain trails.

As part of his discussion of Hawaiian trails, Russell Apple proposed a classification system estimating the construction dates for different kinds of coastal trails (Table 1).

In an expanded compilation of his initial work, Apple completed a computer search of Bishop Museum reports, finding that his classification scheme had been

Peter Mills is an associate professor, Department of Anthropology, University of Hawai'i at Hilo, Hawai'i. 
Table i. Hawaitan Trail Classifications

\begin{tabular}{|c|c|c|c|}
\hline $\begin{array}{l}\text { TRAIL } \\
\text { TYPE }\end{array}$ & ESTIMATED AGE & WIDTH & DESCRIPTION \\
\hline A & $\begin{array}{l}\text { Precontact-early } \\
\text { historical }\end{array}$ & Single-file footpath. & $\begin{array}{l}\text { Following the contours of the } \\
\text { coast; stepping stones placed } \\
\text { over rough lava. }\end{array}$ \\
\hline $\mathrm{A}-\mathrm{B}$ & $1820-1840$ & $\begin{array}{l}\text { Slightly widened from Type A to } \\
\text { accommodate one horse. }\end{array}$ & $\begin{array}{l}\text { Following contours of the coast; } \\
\text { waterworn stepping stones } \\
\text { removed; curbstones added. }\end{array}$ \\
\hline B & $1820-1840$ & $\begin{array}{l}\text { Wide enough to accommodate one } \\
\text { horse. }\end{array}$ & $\begin{array}{l}\text { Built in straight lines inland from } \\
\text { Type A with curbstones. }\end{array}$ \\
\hline $\mathrm{C}$ & $1841-1918$ & $\begin{array}{l}\text { Wide enough to accommodate two } \\
\text { horses. }\end{array}$ & $\begin{array}{l}\text { Straight trails, filled and leveled } \\
\text { with curbstones. }\end{array}$ \\
\hline $\mathrm{D}$ & $\begin{array}{l}\text { Late } 1800 \text { s-early } \\
\quad 1900 \text { s }\end{array}$ & Wide enough for horse-drawn carts. & Same as Type C. \\
\hline
\end{tabular}

Note: derived from Apple 1965.

used 22 times in archaeological reports between 1965 and 1988, and he concluded that his classification had "been accepted in academia" (Apple 1994:36).

Apple's typology was a reasonable preliminary classification of Hawaiian trails, but it still contains assumptions that archaeologists have yet to verify. How do we know, for example, that all prehistoric coastal trails (Type A) closely followed the contours of the coast? Much of the current route considered for the National Historic Trail has curbstones and does not follow the contours of the coast. According to Apple's classification, these sections should be historical routes (Type B, C, or D trails). One well-documented exception to Apple's generalizations about Type A trails is an inland footpath in 'Anaeoho'omalu and Kalahuipua'a that bypasses coastal communities, but passes through a petroglyph field and a stone abrader quarry. Oral histories and archaeological evidence suggest the trail was established in the A.D. 1400s-1600s (Cordy 1994:9). Written records also point to several major late prehistoric trails on Hawai' $i$ Island-both along the coast and following inland routes - that facilitated travel from the windward to the leeward sides of the islands and through various districts (Cordy 1994, 2000 : 47-48). Despite a multitude of documents pertaining to the expansion and improvement of Hawaiian trails in the 1800s (cf. Apple 1965, 1994; Cordy 1994; Kuykendall 1953:23-26), historical records infrequently specify whether or not earlier trails were in the same locations.

\section{THE “TRYANNY” OF THE AHUPUA'A MODEL}

One reason for the limited archaeological research on the Ala Loa may be the way that archaeologists think about Hawaiian landscapes. Ahupua'a (Cordy 2000:3133; Earle 1977, 1987; Handy and Handy 1972:46-48; Kamakau 1976: 7; Sahlins 1992:17-22), or largely self-sufficient land divisions running in narrow bands from the sea to the mountains, dominate archaeological models of traditional Hawaiian landscapes, and by their nature, divide the Ala Loa into small sections. Although virtually all scholars recognize that Hawaiians were capable of traveling 
beyond their own ahupua' $a$, the economic self-sufficiency of ahupua' $a$ has been emphasized. This is what is meant by a "tyranny"; by focusing on ahupua' $a$ as self-sufficient analytical units, important integrative forms of exchange beyond the ahupua' $a$ have been somewhat neglected, despite a general acknowledgment that such exchanges occurred. Coastal trail systems (and the sites associated with them) can be viewed as integrative archaeological features that permeate ahupua' $a$ boundaries. By evaluating various hypotheses regarding the nature of interdistrict exchange, this perspective can bring balance to our models of ahupua' $a$ economics.

On Hawai' $i$ Island by the beginning of the nineteenth century, over $600 \mathrm{ahu}$ pua'a were organized into six larger districts (Cordy 2000:31), or moku o loko. Chiefly land managers (konohiki) lived in each ahupua' $a$, managing the land and collecting tribute from the resident commoners. The konohiki collected tribute for another chief who often lived elsewhere (ali' $i$ 'ai ahupua' $a$ ). In turn, ali' $i$ 'ai ahupua' $a$ owed tribute to a higher ranking chief who controlled the moku (ali' $i$ ' $a i$ moku). Beginning perhaps in the A.D. 1400s, chiefs united the entire island under their rule (such as 'Umi a Lìloa in the A.D. 1600s, and Kamehameha I in the late 1700s), thus establishing a chiefly hierarchy integrating various moku into a single polity.

According to most models, chiefs were responsible for nearly all social integration beyond the level of the ahupua' a, negotiating the political economy through redistributive exchange, alliance, and competition. The annual Makahiki festival, for example, involved priests and other chiefly retinue using the Ala Loa to collect tribute from the various districts (Cordy 2000:61; 'I'i 1959:70-72; Malo 1951:143-144). Carrying an image of the Hawaiian god Lono known as the "long god" (akua loa), chiefly priests would make a clockwise circuit of the island in 23 days. Apple suggested that the circuit of Lono was one of the major reasons why coastal trails connected with those in neighboring ahupua'a (Apple 1994:8). What Apple did not address is how the circuit could be completed in 23 days if it followed meandering routes (Type A trails) along Hawai'i's coastline. Cordy (2000:284) offers a partial explanation, pointing to accounts that some portions of North Kohala collected tribute on separate circuits. Then the tribute was brought to $\mathrm{Pu}$ 'uepa to be retrieved by the main circuit. If bypass trails existed in other areas, they certainly would have facilitated more rapid completion of the Makahiki circuit and other forms of long-distance exchange.

Based upon our understanding of ahupua'a economics, Hawaiian commoners (maka'äinana) traveled outside of their respective ahupua'a much less often than chiefs. Commoners harvested resources from the ocean and land, participating in an interhousehold system of reciprocal exchange within their respective ahupua 'a, and supporting the chiefs with their surplus goods. A variety of scholars (Earle 1977, 1987, 1997; Handy and Handy 1972; Handy and Pukui 1958) have used ahupua'a models to argue for the maximization of self-sufficient communities, where subsistence goods were exchanged between upland and coastal regions, leaving little reason for any commoner to venture outside of her or his community. Russell Apple (1994:9) went so far as to state "passage into or through an ahupua'a would be an act of trespass, potentially punishable by death, if a person from one ahupua'a gathered or collected something without authorization from another ahupua' $a$, especially if he or she attempted to eat it or return home with it, or strayed too far off the beaten path." Timothy Earle stated "the ahupua'a 
were not specialized since territorial divisions were structured to create economically repetitious units. Between districts there were indeed marked environmental differences, but the local subsistence economies remained generalized and largely independent because alternative strategies were available" (1987:224). Earle acknowledged that some interdistrict exchange did occur (1987:224-225; 1997:234), but maintained that interdistrict exchange in Hawai'i was "relatively rare" (1987:225), and "quite limited" (1997:234).

Ross Cordy takes a more balanced position, discussing common exchange across neighboring ahupua'a boundaries on coastal trails, but suggests that longer travel by commoners was less frequent:

The common use of the ala loa was for interaction between people of adjacent communities. The residents of ahupua'a prior to the 1800s rarely travelled far from their ahupua'a. Farming, fishing, and gathering of forest resources were usually done within the bounds of their own ahupua'a. Most marriage partners came from the same ahupua'a or from nearby lands. Many small sets of ahupua'a commonly interacted in the past. The main means of travelling between these communities was on the ala loa.

Longer distance travel by commoners, although less frequent, would also have been along the ala loa, its upland branches, across the mountain trails, or by canoe. Some of this traffic may have been for the overlord chiefs and the rulers, such as the bringing in of daily food supplies and water.

Travel along the ala loa also was done for chiefly affairs. Messengers were sent along trails or by canoe to call in other chiefs for meetings, to call for tribute, to summon warriors in for battle, to gather in laborers to build public works projects such as temples, and so on. (Cordy 1994:6)

Straight trails that bypassed small coastal communities would not have been necessary or even beneficial to commoner exchange if it was largely limited to exchange between adjacent communities. Nevertheless, straight trails would have facilitated commoner exchange that involved travel over greater distances, as well as the chiefly affairs mentioned by Cordy and others.

Marshall Sahlins (1992:19-20) also posits that regular patterns of exchange between ahupua'a occurred, at least within moku:

In identifying their social appurtenances, ordinary people spoke of the ahupua'a as their 'aina, their 'land' ... a usage that seems to reflect the capacity of the territory to support a totality of social being. In the same way, the set of neighboring ahupua'a making up a moku division constituted a coherent ecological scheme at a higher level of organization ...

In some places such as the Ka' $\overline{\mathrm{u}}$ division of Hawai' $\mathrm{i}$, the complementarity among ahupua' $a$ - and therefore the cohesiveness of the moku-is sustained by boundary arrangements that give peripheral districts exclusive access to upland forests or deepsea fishing grounds. The effect is a certain specialization of production by ahupua'a in canoe building, bird snaring, or fishing.

Sahlins presents well-known ethnohistorical cases of exchange between ahupua' $a$, and there are others. John B. Whitman, a resident of Honolulu between 1813 and 1815 wrote "the business of exchanging one commodity for another is carried on by peddlers called by the natives Pee-erry [Piele]. These travel from one district to another carrying their wares in large calabashes, though I could never discover the ultimate object of the Pee-erry man as it seems he cannot acquire riches or accumulate great store of perishable commodities" (Whitman 1979:60). This account clearly suggests that Hawaiians of low status were reg- 
ularly engaged in interdistrict exchange on $\mathrm{O}^{\prime}$ ahu in the early historical period. Kamakau (1976:123) also mentioned low class commoners who peddled goods between districts: "the peddlers' only master was Maoloha [whose legendary net scattered food]. Peddlers were not allowed in the houses of chiefs; they could not eat with them. A peddler was like a defiled person, kanaka haumia, in ancient times."

In addition to low class trade specialists who moved small quantities of commodities between districts, there are indications of regularized large-scale interdistrict exchanges. Handy and Handy (1972:314-315) wrote that in "Old Hawaii," people from Waipi'o Valley on the northeast coast of Hawai'i regularly shipped out compact poi ( $\mathrm{pa}^{\prime} \mathrm{i}^{\prime} \mathrm{ai}$ ) to Hilo and Kohala in exchange for fish. Also, Puna would receive fish from neighboring districts in exchange for hala (Pandanus tectorius), which was used to make mats, and wiliwili (Erythrina sandwicensis) wood in Ka' $\mathrm{u}$ was exchanged for koa (Acacia koa) wood from Kona. Both districts would use the exchanged wood to fashion different portions of canoes (Kahopukahi, in Fornander 1916-1920, vol. 5:618-620). The missionary William Ellis in 1823 (1963:229-230) also described "fairs" regularly held in Hilo where Hawai'i Island residents from the south and southeast districts of $\mathrm{Ka}^{\text {' }} \mathrm{u}$ and Puna exchanged dried fish, mats, tapa, dried taro, and tobacco with people from the northeastern district of Hāmākua.

Archaeological data further support the idea that there was significant movement of domestic goods across ahupua'a boundaries. Quarries for adze stone have been identified on all the main Hawaiian islands (Sinton and Sinoto 1997:200), and at least some of the quarried rock appears to have been part of extensive prehistoric exchange networks. Concentrations of scoria abrader quarry sites on Hawai'i Island (e.g., Kirch 1979:18-70) are extensive enough to suggest that they were being exploited for distribution beyond the local community. Other materials, like volcanic glass, found ubiquitously in prehistoric Hawaiian midden deposits, are not always available in a particular ahupua'a, thus suggesting exchange of this raw material.

Determining the sources of lithic materials found in Hawaiian archaeological sites is beginning to play an important role in the identification of prehistoric exchange (Cleghorn et al. 1985; Hay et al. 1986; Hunt and Graves 1990; Lass 1994; McCoy 1990; Sinton and Sinoto 1997; Weisler 1990a, 1990b; Withrow 1991), but has yet to be conducted on a scale that is large enough to form accurate and quantitative diachronic generalizations regarding the distribution of raw materials across ahupua'a boundaries. For example, Barbara Lass (1994) conducted petrographic analysis of 155 adze fragments from various domestic sites in three adjacent moku (Kohala, Kona, and Ka' $\bar{u}$ ) on the island of Hawai'i (also see Withrow 1991). She found that 102 of these samples were made of material similar to the basalt from the Mauna Kea quarries. Even though the Mauna Kea adze quarries were located in the moku of Hāmākua at historical contact, Lass argued that her data do not represent directed exchange controlled by chiefs, but commoner giftexchange or equal access to a centrally located resource by all island inhabitants. Whether or not the data support exchange through chiefly redistribution or generalized reciprocity, they do indicate that a significant proportion of prehistoric adze material on Hawai'i was not obtained within a system of self-sufficient ahupua'a (or larger island districts for that matter). 
Prehistoric travel by trail systems and sea travel would have been important aspects of this domestic economy, and there is little reason to suggest that only chiefs carried basic commodities between ahupua' $a$. Unlike travel in canoes, trails left behind readily visible archaeological features. These features can be potentially dated and studied to determine the range of activities occurring along them, as well as the level of labor invested in their construction. Instead of focusing on ahupua' $a$ as self-sufficient economic units, studying coastal trails can help us investigate how people living in various ahupua' $a$ involved themselves in integrative networks through lateral exchange systems.

\section{THE OLD GOVERNMENT BEACH ROAD SURVEY}

In 1998, students in the University of Hawai' $i$ at Hilo archaeological field school surveyed a two-mile section of the Ala Loa in North Kona, most commonly referred to by locals as the "Old Government Beach Road." This section crosses through a dozen ahupua'a (Fig. 1), and lies between the more celebrated bays of Kealakekua to the south and Keauhou to the north. It is one of the few remaining portions of the road in North Kona that has not been altered by large-scale modern development or jeep traffic, and passes through dense prehistoric and early historical settlements that have been only marginally surveyed (Ahlo 1981; Reinecke 1930; Soehren 1980a, 1980b; Stokes and Dye 1991). Immediately to the north, the trail enters a resort complex in Keauhou, and directly to the south, a large development is underway, known as "Oceanside 1250," or Hokuli'a.

Hawaiians designed their trails in accordance with their cultural patterns of settlement and livelihood. Cordy (2000:130-136, 382) suggests that permanent settlement of leeward Hawai'i occurred in the A.D. 900s-1100s, with an initial focus on cultivating upland areas, with temporary habitation sites established near the sea. This would support the idea that early trails ran from the uplands to the coast (mauka-makai trails) in Kona. By the late prehistoric period, many-but certainly not all-residences were near the sea, to take advantage of the veritable supermarket of resources such as fish, salt, shellfish, and edible seaweed. Russ Apple concluded that most fisherman's trails along the coast ran true as possible to the contours of the shoreline except where topography made the coastline impassable. In the latter case, the trail would detour inland near village sites (Apple 1994:6).

Fishing was an important source of protein, but fish occupied a small part of most Hawaiian diets. Most sustenance continued to come from cultivated lands in fertile upland regions, thus any number of mauka-makai trails between sea and mountain continued to facilitate travel and exchange goods between the coast and the uplands (Apple 1994:2). Prior to the mid-nineteenth century, people lived along and above the Ala Loa in dispersed communities. The fields these families tended were part of the "Kona field system" an extensive precontact agricultural complex which ran for 18 miles through North and South Kona, mostly above the Ala Loa, and between $150 \mathrm{~m}$ and $900 \mathrm{~m}(500 \mathrm{ft}$ and $3000 \mathrm{ft}$ ) in elevation (Cordy 2000:248-258; Kelly 1983:71; Kirch 1985:225-230; Maly and Smith 1999:13-19). Physical remnants of the Kona field system are preserved in many areas and can be readily detected on the ground, although it was aerial survey around Kealakekua Bay that resulted in the first official report of the ex- 


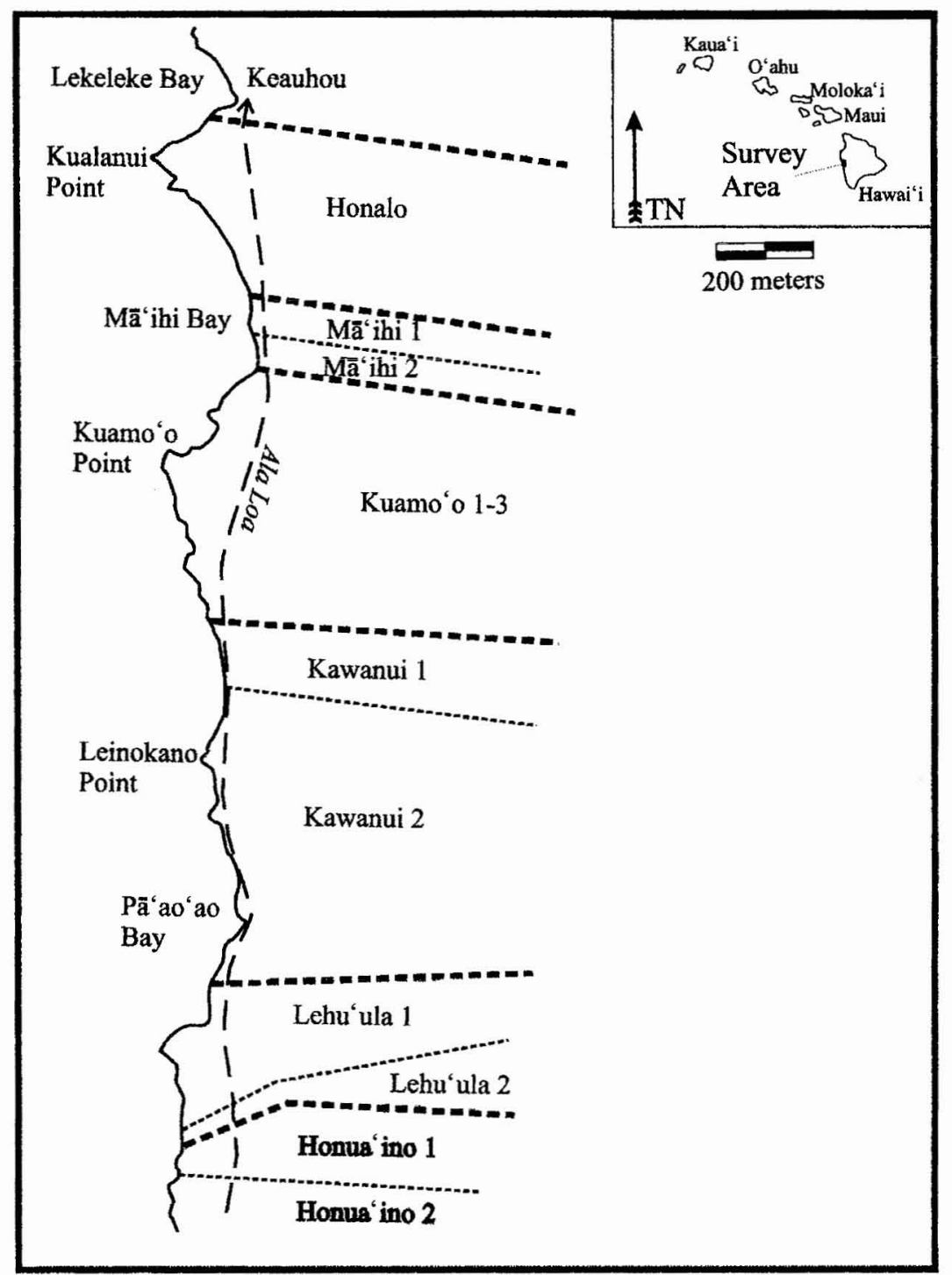

Fig. 1. Location of the Ala Loa in relation to ahupua'a in the survey area.

tensive stone and earth field boundaries that typify the system (Soehren and Newman 1968). This field system could have supported a very large population in the ahupua' $a$ through which it extended.

The crucial question is whether or not the straight coastal trail connecting various ahupua' $a$ was also part of this settlement pattern, despite the well-documented strong ties between upland and coastal regions. Following Apple's typology, this section of the Ala Loa superficially matches the features of a "Type B" trail, with numerous curbstones placed in roughly straight lines, not closely following the contours of the coast. Therefore, Apple's typology would place the initial construction of this section of trail in the historical era, sometime after A.D. 1820. 
The 2-mile segment of the Old Government Beach Road crosses several 'a'ā and pāhoehoe flows on the leeward shield of Hualālai Volcano. The northern quarter of the trail segment passes over nearly bare lava flows, with small pockets of friable ash, sand, and gravel in depressions. The limited soil development has allowed several invasive plant species, particularly kiawe (Prosopis pallida) and koa haole (Leucaena leucocephala), to establish a sparse canopy. Towards Mā'ihi Bay, a shallow soil composed of volcanic ash between numerous pāhoehoe outcrops predominates. This in turn is replaced by a greater degree of exposed pāhoehoe and ' $a$ 'a as one proceeds south into the ahupua' $a$ of Kuamo'o, Kawanui, and Lehu'ula, although a thick koa haole overstory is still present. Near the southern terminus of the trail section, there is a level coastal terrace at the old coastal village site of Kāināliu in the ahupua'a of Honua'ino. Ashy soils here are shallow to moderate in depth, with some bedrock outcrops, but support old growth kiawe up to a meter in diameter. Nevertheless, there are small areas along the trail where trees first introduced to Hawai' $i$ by early Polynesian settlers still thrive. For example, coconut (niu, or Cocos nucifera) and kukui (Aleurites moluccana) trees can be seen penetrating the canopy of kiawe and koa haole in coastal Kāināliu.

Like much of the arid leeward coast of Hawai'i Island, one of the most constraining factors for human subsistence is access to fresh water, both for crop cultivation and for personal consumption. Although average annual rainfall for this section of the Kona Coast is around 40 inches per year (Giambelluca and Schroeder 1998:57), much of this comes in storms of short duration and is lost as run-off. There are no ponds or perennial streams, but two ahupua' $a$ along this section of trail, Honua'ino and Mā'ihi, have spring water at or near the surface. The springs at Honua ino have been used historically by the beach community, and the spring at Mā'ihi is used to supply drinking water to cattle.

\section{SURVEY METHODS}

Our survey methods were based on tape-and-compass mapping, collection of Global Positioning System (GPS) reference points, and topographic data generated from an autolevel. Property owners along the trail also provided us with the opportunity to survey some of the land between the shore and the trail, and various inland portions as well. Adjacent properties from Kuamo'o to Honalo were not available for survey, but data from surveys in the 1980s (Ahlo 1981; Soehren $1980 a, 1980 b$ ) have documented much of the coastal settlement pattern in Honalo. All of the field maps were digitized and used as templates to draft finished versions in Corel Draw. The composite map, initially drafted at a scale of $1: 200$, provides a detailed map of the coastal trail that is over $12 \mathrm{~m}$ long. The digitized files now form one JPEG file which can be viewed at various scales, and a two-volume report (Mills and Irani 2000) was completed on the trail for the State's "Trails and Access Program" (Na Ala Hele, State Department of Land and Natural Resources).

\section{RESULTS}

Although we had access to much of the coastline, we identified no evidence of multiple trails running along the coast in this area, even in areas where rough 
prehistoric ' $a$ ' $\bar{a}$ flows cover the surface. Coastal erosion and mass-wasting of the low cliffs may have damaged certain portions of trails that more closely followed the coast, but the straight inland route appears to be the only well-established trail in the area. Recent surveys in the area directly south, however, demonstrate that the pattern is more complex in those ahupua' $a$. In Hōkūkano (to the south), a stepping stone trail closely follows the contours of the coast, passing through dense coastal settlements, while the presumed nineteenth-century Old Government Beach Road proceeds southward on a straight inland route, with little evidence of associated pre-European settlements (Oceanside Partners 2000). In our survey area to the north, even along the most arid and stony sections of the trail, there is evidence of old house platforms and cultivation areas. With the limited soil development, much of the domestic refuse still lies on the surface. Surrounding some domestic structures are artifacts such as basalt flakes from prehistoric or early historical adze manufacturing, often intermixed with broken ceramics and bottle glass. Later historical features along the trail (i.e., gates and rubble-filled walls) testify to global economic forces that affected traditional ahupua'a-based exchange systems. The walls adjacent to the road also delimit historical property boundaries tied to fee-simple property ownership, which often corresponded with earlier ahupua' $a$ boundaries.

The Old Government Beach Road, like the sites that surround it, is an amalgamation of construction episodes. It varies considerably in visibility, construction methods, width, and integrity from location to location. Given the extensive historical use of this area for ranching and agriculture, it should be expected that any prehistoric features should be more difficult to identify. Nevertheless, various features reflect patterns that could be associated with prehistoric as well as historical travel across ahupua'a boundaries. Trails are difficult to date directly, but by examining patterns in sites near trails and different methods of trail construction, it may be possible to form working hypotheses on a particular trail's chronology.

\section{ASSOCIATION WITH PREHISTORIC FEATURES}

The primary issue needing resolution is whether or not the trail was in existence when nearby prehistoric features were built. While Apple's typology suggests this trail route was established after 1820 , several correlations can be drawn between the location of prehistoric sites and the trail. Several heiau, petroglyphs, a hōua slide, house clusters containing stone tool chipping debris, dryland agricultural features, and burial sites are adjacent to the road, presumably reflecting traditional Hawaiian land uses associated with the ahupua' $a$ system.

In the 2-mile survey area, coastal heiau are positioned directly adjacent to the trail, or within a few hundred meters of it, either toward the coast or inland (Fig. 2). Although foot paths can be discerned running from the main trail toward some of the more distant heiau, these may be from modern travelers. In many cases, these branch trails appear to have been on the unmodified level surfaces of small lava tubes. No formal trails were identified that approached the more distant heiau from any direction. Nevertheless, because heiau were not positioned in a straight line, and were sometimes located for visual effect on promontories, a trail that was designed to facilitate commodity exchange (prehistoric or historical) should not be expected to lead directly to them. For example, a heiau that John 




Fig. 2. Select sites located near the Ala Loa.

Stokes identified as 'Ūkanipō in Lehu'ula 1 in the early 1900s (Stokes and Dye 1991:93) is positioned on a low promontory several hundred meters inland from the Ala Loa, and would have diverted the trail from its straight course. In fact, the trail looks much like a regression line. This could be a coincidental correlation, but if it is not, it would indicate that the trail allowed for quick travel between districts, yet remained as close as possible to the coastal heiau without diverting the road from a nearly straight course. If the main trail had been designed for the sole purpose of the annual Makahiki festival, one might expect that the Ala Loa would lead directly to the main coastal heiau in each district. This finding suggests 
that the trail was not primarily designed for the ritual movement of chiefs between various heiau.

The trail directly abuts heiau in Kawanui 1 ( $\mathrm{Pu}$ 'o'a heiau), and in Mā'ihi 1 (Kekuaokalani heiau). Both Pū'o'a heiau and Kekuaokalani heiau are adjacent to the coastal cliff with the trail running along the inland (mauka) side. Little is known about either heiau, but Kekuaokalani may have been built in 1819, and named after the chief who lost the battle near this spot for the retention of the kapu system. At Kekuaokalani heiau, intact dry-laid stone walls without any rubble fill are aligned with both sides of the trail, suggesting that the trail was present when these wall segments were built. Stone walls lacking rubble fill were common in pre-European times, and rubble-filled walls appear more common in nineteenth-century and twentieth-century sites (Ladefoged 1991).

A factor supporting the hypothesis that this trail was present in prehistoric times is the location of petroglyphs. The majority of petroglyphs identified in the survey were located in one cluster, with the trail running directly through the petroglyph field near the boundary of Lehu'ula 1 and Lehu'ula 2 (Figs. 1 and 2). All of the petroglyphs are traditional prehistoric motifs, particularly poho (cupules), and anthropomorphic designs. The concentration of numerous poho interspersed with anthropomorphic figures in association with a trail fits the pattern of some larger and better known petroglyph fields on Hawai'i Island, such as Pu'u Loa in Hawai'i Volcanoes National Park (Lee and Stasack 1999:83-104).

J. Halley Cox and Edward Stasack $(1970: 28)$ provide a few additional thoughts on petroglyphs near trails:

Petroglyphs on trails ... may have some connection with the makahiki activities. It was at the boundaries of the ahupua' $a$ on the coastal trails that the pig-altars for the makahiki ceremony were located...

By no means are all boundaries marked by petroglyphs, and many petroglyphs do occur in patterns that seem unrelated to trails and boundaries; but it should be remembered that some of the present property lines may not be ancient boundaries, even though the names of ahupua' $a$ and districts are ancient, and that in many areas the ancient trails are now not visible.

Petroglyphs along ahupua 'a boundaries are also well documented in Puakō (Lee and Stasack 1999:13,14), where several petroglyph clusters follow the ahupua' $a$ boundary. Since Lehu'ula 1 and Lehu'ula 2 are very narrow ahupua' $a$, it is difficult to use this isolated case to support the conclusion that petroglyph clusters were intentionally placed on ahupua'a boundaries.

House yard walls flank the trail in various locations. This is particularly true in Honalo, where the most dense concentration of domestic features are located. Walls built around mid-nineteenth-century land awards (kuleana) line the trail on both sides. In Lehu'ula, the trail separates house lots containing stone tool chipping debris (on the inland side) and burial features on the seaward side located on top of the coastal cliff. Most notably for the entire 2-mile section of trail, there are no clear foundation remnants from walls that had crossed over the trail at some point in the past. If in fact prehistoric walls and house lots had crossed the route of the current trail, all evidence of the associated walls has been removed.

Another feature of note is a hōlua slide in the ahupua' $a$ of Honalo. Hölua slides were built with foundations of stone and allowed Hawaiian athletes to ride a 
wooden sled (papa) down a steep slope. An early Bishop Museum survey (Reinecke 1930) identified the hōlua slide, but it was no longer a visible archaeological feature in the area that we had permission to survey. Nevertheless, Reinecke clearly described its location, and it would have run over the location where the trail is. Extensive road fill at this location in Honalo indicates that at least this portion of the trail was modified into a level roadbed following the abandonment of the slide, and offers support to Apple's conclusion that the filling and leveling of Hawaiian trails was a historical event.

At first glance this would appear to be evidence that the trail was not in existence when the hōlua slide was in use, and in fact Apple (1965:27) wrote that "we were certain that a royal sled track [at Hōnaunau] would not be crossed by commoners." If Apple's assumption is correct, the large hōlua slides in Kona would have been a major impediment to overland inter-ahupua'a travel. Unless oral traditions point to kapu against such crossings, however, it should remain an open question whether or not the Ala Loa was designed in such a way that people could cross over hōlua slides, similar to modern railroad crossings or other intersections.

\section{WATERWORN STEPPING STONES}

Waterworn stones provide some of the most telling evidence that a prehistoric trail may have existed in this location. The Kona missionary Lucy Thurston wrote that Governor Kuakini and other "first-class chiefs" had horses that were broken to ride by 1825 (Thurston 1934:227), and Apple (1965:34) argued that horse traffic on waterworn stones was an unsuitable combination, and would have precluded Governor Kuakini's use of waterworn stones in his efforts to improve trails. If Apple is correct in this assumption, the monumental effort involved in hauling thousands of waterworn stones from the shore to build this section of trail would predate Governor Kuakini's nineteenth-century road-building efforts. Nevertheless, Apple's assumption is not above question; nineteenth-century chiefs on Maui still apparently used some waterworn stones to rebuild portions of the "King's Trail" or "Hoapili Trail" on Maui. On Hawai'i Island, oral traditions clearly document that chiefs on horseback, and later, ranchers, intentionally removed waterworn stepping stones from old trails because horses would slip on them (Apple 1965:34, 1994:36; Kelly 1972:8; William Paris, in Maly and Smith 1999, vol. $2:: 7)$.

We made an effort to identify all the visible waterworn stones along the entire 2 -mile route. Today, waterworn stones tossed to the sides of the road are much more common than those remaining in the road bed. Since most coastal access from the road is limited by cliffs, and because waterworn boulders are not found in all locations along the coast where we found them along the trail, the presence of these boulders reflects organized and intensive labor. In order to compare the frequency of waterworn stones along the 2-mile trail segment, the length of trail in each ahupua' $a$ was divided by the number of waterworn stones observed along that length. This provides an average distance between visible waterworn stones (Table 2). Because our survey team probably missed boulders that are now buried in filled sections of the road or scavenged for other purposes, this average is almost certainly a maximum average distance between waterworn stones. 
Table 2. Waterworn Stones by the Ala Loa

\begin{tabular}{|c|c|c|c|c|}
\hline AHUPUA'A & $\begin{array}{c}\text { NUMBER OF } \\
\text { WATERWORNS }\end{array}$ & DISTANCE & m/WATERWORN & SURFACE \\
\hline Honua ino 2 & 0 & 114 & $>114$ & Shallow soil \\
\hline Honua'ino 1 & 0 & 128 & $>128$ & Shallow soil \\
\hline Lehu'ula 2 & 0 & 104 & $>104$ & Shallow soil, pāhoehoe \\
\hline Lehu'ula 1 & 9 & 230 & 25.56 & Pāhoehoe \\
\hline Kawanui 2 & 268 & 686 & 2.56 & Pāhoehoe-'a'ā \\
\hline Kawanui 1 & 13 & 146 & 11.23 & Pāhoehoe \\
\hline Kuamo'o 1-3 & 54 & 538 & 9.96 & Rough pāhoehoe \\
\hline Ma‘ihi 2 & 0 & 77 & $>77$ & Shallow soil \\
\hline Ma'ihi 1 & 1 & 84 & 84 & Pāhoehoe \\
\hline Honalo & 106 & 422 & 3.98 & Rough pāhoehoe \\
\hline
\end{tabular}

No waterworn stones were observed along the trail in the ahupua' $a$ of Honua'ino, Lehu'ula 2, and Ma'ihi 2, even though significant portions of the route are covered with smooth pāhoehoe flows and shallow soils not deep enough to obscure waterworn boulders. It seems that these portions of the road were not paved. Nine waterworn stones lie adjacent to the trail in Lehu'ula 1, far too few to account for a regularly paved waterworn surface. But 75 waterworn stones, which may have been scavenged from the road bed, are scattered throughout a residential complex to the east of the trail in this same area.

In contrast, Kawanui 2 shows a significantly different pattern, with 268 waterworn stones along $686 \mathrm{~m}$ of trail, or an average of 1 stone every $2.55 \mathrm{~m}$. The concentration is even more marked when the variable of surface geology is considered. The central $440 \mathrm{~m}$ of trail in Kawanui 2 is covered in an 'a'a flow, where 250 waterworn stones are present (an average of one waterworn stone every $1.76 \mathrm{~m}$ ). The trail here is separated from the coast by steep cliffs, and this concentration reflects a high labor investment. Other relatively high concentrations of waterworn stones lie in Kuamo'o and Honalo, where pāhoehoe flows are often slabby, with a rough surface.

Curbstones are another feature of the trail that are frequently associated with nineteenth-century trail modifications, and are often explained in the literature as having been constructed to help horses see the road (Apple 1965:34, 1994:36; Cordy 1994:9). Despite the fact that many curbstones are clearly historical additions to trails, experienced horse-riders that I have spoken to question the hypothesis that the curbs were for horses. Furthermore, in the dryland agricultural fields of Kohala, curbstones have been identified on some prehistoric mauka-makai trails (Kaschko 1973:127-128), or those running from the mountains to the coast, calling into question the validity of assuming that all curbstones are historical features. In one location along the Ala Loa in Kona, we found curbstones along a slightly undulating edge of pāhoehoe flow in Honua'ino. This curb made a straight line out of an undulating bit of nature, and served no practical purpose in widening or leveling the road. I propose that curbing of historical trails may have carried a symbolic importance more than a practical one. Whether or not these features are solely historical remains to be proven. 


\section{SOURCES OF DRINKING WATER}

One greatly underemphasized factor regarding traditional subsistence in leeward Hawai' $i$ is access to drinking water. All evidence suggests that large and permanent communities lived along the Kona coast, yet few of these people had direct access to a consistent supply of fresh water. In 1823, William Ellis wrote that water "is one of the most acceptable presents a captain going to this station [Kailua-Kona] could make, either to chiefs or missionaries" (Ellis 1963:29). Liquid in coconuts could partially alleviate this shortage, but in some arid parts of Hawai'i Island, coconuts were kapu to all but the chiefs (Beckwith 1970:95). Some water from moisture dripping into caves was collected in gourds or carved troughs (Handy and Handy 1972:64-67). In the historical era at Punalu'u in the $\mathrm{Ka}$ ' $\overline{\mathrm{u}}$ district, fresh spring water was collected by divers in the bay with empty bottles who gathered the spring water at its undersea source before it mixed with the ocean water. Springs were highly coveted and often tied to Hawaiian mythology, particularly Kāne and Kanaloa (Handy and Handy 1972:64-65).

Considering the surface geology and our field observations, drinking water would have been scarce along the coast for people living in Kuamo'o, Kawanui, and Lehu'ula. The closest sources of fresh water within each of these ahupua'a may have been several miles inland at elevations over 490 meters (ca. 1,600 feet). Alternatively, several springs that exist along the coast in Honua'ino and Mā'ihi (Fig. 2), could have provided drinking water to all the communities along the trail with much less travel involved, and without having to ascend the slopes of Hualālai. The effort required to reach these distant inland sources would have greatly taxed the net-gain from the water obtained. It is therefore possible-if not likely - that nearby water sources in adjacent ahupua' $a$ were regularly exploited in an exchange network crossing ahupua' $a$ boundaries. Such exchange would help explain the existence of efficiently designed coastal trails. Springs in Honua ino and $M a a^{\prime}$ ihi have been heavily used throughout the historical era, and several pump-houses have been constructed in both ahupua' $a$ directly adjacent to the trail route. Nevertheless, there is no current proof that the springs were used prehistorically. Further archaeological and historical research on coastal leeward springs, and their association with coastal trails, may help clarify this issue.

\section{CONCLUSIONS}

Despite hundreds of years of trail modifications, an analysis of prehistoric sites and trail features associated with the Ala Loa in North Kona provides useful information on early Hawaiian trails, and demonstrates a pattern consistent with selective placement of waterworn stones over rough lava flows on a straight trail running through numerous ahupua'a. Even though we can no longer see an intact stepping stone trail in this 2-mile segment, evidence suggests that one did exist in the same location as the nineteenth-century road, and followed much (if not all) of the same straight route as the historical road. This coastal trail can be seen as an extensive archaeological feature reflecting high investments in social integration across ahupua' a boundaries. Such trails do not fit within Russ Apple's Hawaiian trail typology. Apple's A-B trails closely follow the contours of the coast, which this one does not, and Apple's Type B, C, and D trails were supposedly built after 
1820, without stepping stones, and in straight lines where there were supposedly no former trails. Apple's typology either needs to be modified to allow for stepping stone coastal trails that were built in straight lines after 1820 , or to allow for the existence of some Type B trails built with stepping stones before 1820 .

Looking at several combined factors in addition to the presence of stepping stones, some evidence suggests that the trail may be prehistoric. These factors include the lack of any well-established meandering trail route along the coast, and frequent prehistoric sites located along the trail (a petroglyph field, house middens with stone tool chipping debris, and heiau). The main factor that does not support the hypothesis that the trail was prehistoric is the reported holua slide in Honalo which crosses over the trail route; either this was an acceptable arrangement, or the two features are not contemporaneous. When the trail was established (either prehistorically or in the early nineteenth century at the latest), travelers did not have to meander along the contours of the coast. Instead, the trail allowed people to quickly traverse each ahupua'a. While this design might be explained by the desire for efficiency in completing a ritual circuit of the island during the Makahiki festival, the road may have also supported domestic exchange of various commodities along the Kona coast, from tool-making materials to food surpluses to fresh drinking water.

Rigorous examination and dating of trail features and associated sites could help establish a diachronic model of the significance of trails and their reflection of changes in Hawaiian land use and commodity exchange across ahupua' $a$ boundaries. In particular, considering trails as integrative elements in Hawaiian domestic exchange systems can provide balance to ahupua'a models in Hawaiian archaeology. With the increasing complexity of Hawai'i's political economy in late prehistory and continuing into the era of the Hawaiian Monarchy, ahupua'a appear to have been divided into progressively smaller units of production. This pattern can be identified in the survey area (e.g., Mā'ihi 1 and 2; Kuamo'o 1-3, Kawanui 1 and 2) where subdivided ahupua'a carry the same name. In the Kohala field system, border walls on fields also demonstrate a general pattern in which larger fields were progressively partitioned into smaller production units (Ladefoged and Graves 2000). Such partitioning may have had more to do with the expansion of the chiefly hierarchy than an ecological determination that smaller ahupua'a could be self-sustaining. Thus, as ahupua'a were subdivided, scarce resources-such as drinking water in arid areas-may have become less available in certain districts, and would have increased the need for regular exchange with neighboring areas where the resource was more readily available.

Beyond the need for lateral exchange to meet the basic necessities of life, certain goods may have been exchanged across ahupua' $a$ boundaries because of their perceived social value. For example, as Barbara Lass (1994:48) points out, many stone sources in the Hawaiian Islands could be used to make adzes. Yet the immense quarries located high on the slopes of Mauna Kea in the ahupua'a of Ka'ohe, Hāmākua district, reflect an intensive exploitation of a high-quality lithic

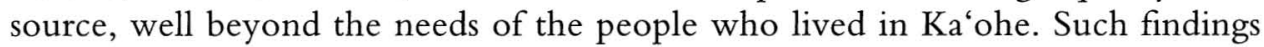
imply that lateral exchange across ahupua' $a$ boundaries did occur, and was driven by social factors transcending basic necessity. These observations do not conform with Earle's concept of maximally self-sufficient and repetitious economic units, especially when residents of ahupua'a chose to use a socially valued nonlocal re- 
source, even when functionally similar resources were available in their own ahupua'a. In light of such observations, the prehistoric development of the Ala Loa becomes an important aspect for understanding the structure of Hawaiian exchange systems and the relative permeability of ahupua'a boundaries.

\section{ACKNOWLEDGMENTS}

Survey of the Old Government Beach Road was facilitated by the Division of Forestry and Wildlife, Trails and Access Program (Na Ala Hele), particularly Pat Thiele and Rodney Oshiro. Special thanks go to Councilwoman Nancy Pisicchio and the late Don Gatewood for their assistance with logistics. Other assistance was provided by the Thompson family, Patricia Grant, Jean Greenwell, Humphrey Hilton, Tony Jose, Kepā Maly, Billy Paris, Richard Stevens, and Allen Wall. UH Hilo field school participants included Tanya Barela, Ed Blackiston, Sheila Bordier, Morgan Frazier, Rick Gmirkin, Bill Hoffman, Keith Hopkins, and Kelly Linn. I also wish to extend my thanks to Ross Cordy, Tom Wolforth, and anonymous reviewers of this paper for their stimulating discussions and critiques.

\section{REFERENCES CITED}

Ahlo, Hamilton

1981 Final report of an intensive archaeological survey at Honalo Makai, North Kona, Hawai' ${ }^{\circ}$ (TMK 7-9-05:13). Ms. at Hamilton Library, University of Hawai'i, Mānoa.

Apple, Russell A.

1965 Trails: From Stepping Stones to Kerbstones. B.P. Bishop Museum Special Publication 53. Honolulu: Bishop Museum.

1994 Ala Kahakai: Trail by the Sea. Macappleville Press, Hawai‘i National Park.

Beckwith, Martha W.

1970 Hawaiian Mythology. Honolulu: University of Hawai'i Press.

Cleghorn, Paul L.

1982 The Mauna Kea Adze Quarry: Technological Analyses and Experimental Tests. Ph.D. diss. University of Hawai'i, University Microfilms, Ann Arbor.

Cleghorn, Paul L., Tom S. Dye, Marshall Weisler, and John Sinton

1985 A preliminary petrographic study of Hawaiian stone adze quarries. Journal of the Polynesian Society $94: 235-251$.

Cordy, Ross

1994 The Ala Kahakai Trail-Or the Ala Loa: An Archaeological and Historic Preservation Perspective. Unpublished manuscript on file, State Historic Preservation Division, Honolulu.

2000 Exalted Sits the Chief. Honolulu: Mutual Publishing Company.

Cox, J. Halley, and Edward Stasack

1970 Hawaiian Petroglyphs. Honolulu: Bishop Museum Press.

\section{EARle, Timothy $\mathrm{K}$.}

1977 Economic and Social Organization of a Complex Chiefdom: The Halelea District, Kaua'i, Hawai'i. University of Michigan, Museum of Anthropology, Anthropological Papers No. 64. Ann Arbon, Michigan.

1987 A reappraisal of redistribution: Complex Hawaiian chiefdoms, in Exchange Systems in Prehistory, edited by Timothy Earle and Jonathon E. Ericson. New York: Academic Press.

1997 Exchange in Oceania: Search for evolutionary explanations, in Prehistoric Long-Distance Interaction in Oceania: An interdisciplinary approach, pp. 224-237, ed. Marshall I. Weisler. New Zealand Archaeological Association Monograph 21. Auckland.

Ellis, William

[1827] Journal of William Ellis. Honolulu: Advertiser Publishing. 


\section{Fornander, Abraham}

1916- Collection of Hawaiian Antiquities and Folklore, ed. Thomas G. Thrum. Memoirs of the 1920 Bernice Pauahi Bishop Museum 4(6). Honolulu: Bishop Museum.

Giambelluca, Thomas W., and Thomas A. Schroeder

1998 Climate, in Atlas of Hawai 'i, 3rd ed., pp. 49-59, ed. Sonia P. Juvik and James O. Juvik. Honolulu: University of Hawai'i Press.

Handy, E. S. Craighill, and Elizabeth Green Handy

1972 Native Planters in Old Hawai' $i$. B.P. Bishop Museum Bulletin 233.

Handy, E. S. Craighill, and Mary Kawena Pukui

1958 The Polynesian Family System in Ka'u, Hawai'i. Wellington, New Zealand: Polynesian Society, Inc.

Hay, Deborah, Alan E. Haun, Paul H. Rosendahl, and Craig J. Severance

1986 Kahalu'u Data Recovery Project: Excavations at Site 50-10-37-7702 Kahalu'u Habitation Cave, Land of Kahalu'u, North Kona, Island of Hawai'i. Report 61-022084. Hilo: Paul H. Rosendahl, Inc.

Hunt, Terry L., and Michael W. Graves

1990 Some methodological issues of exchange in oceanic prehistory. Asian Perspectives 29(2): 107-116.

'I'I, JOHN PAPA

1959 Fragments of Hawaiian History. Honolulu: Bishop Museum Special Publication 70.

Kamakau, Samuel $M$

1976 The Works of the People of Old: Na Hana a ka Po'e Kahiko. Honolulu: Bishop Museum Press.

KaschKo, Michael W.

1973 Functional analysis of the trail system of the lapakahi area, in Lapakahi, Hawai ' $i$ : Archaeological Studies, ed. H. D. Tuggle and P. B. Griffin, pp. 127-144. Asian and Pacific Archaeological Series No. 5. Honolulu: Social Science Research Institute, University of Hawai'i at Mānoa.

KeLLy, MARION

1972 Exploring Hawaiian coastal trails: Anaehoomalu, So. Kohala to Kukio, No. Kona, Hawai'i, July-August 1972. Draft report Ms. No. 090672. Honolulu: Bishop Museum.

1983 Na' ma'la o Kona: Gardens of Kona. Department of Anthropology Report Series 83-2. Honolulu: Bishop Museum.

Kirch, Patrick V.

1979 Marine Exploitation in Prehistoric Hawai " $i$ : Archaeological Excavations at Kalähuipua' a, Hawai ' $i$ Island. Pacific Anthropological Records 29. Honolulu: Bishop Museum.

1985 Feathered Gods and Fishooks. Honolulu: University of Hawai'i Press.

KuyKendall, RaLPH

1953 The Hawaiian Kingdom Volume II, 1854-1874. Honolulu: University of Hawai'i Press.

LADEFOGED, THEgN

1991 Hawaiian architectural transformations during the early historical era. Asian Perspectives $30: 57-69$

Ladefoged, Thegn, and Michael Graves

2000 Evolutionary theory and the historical development of dry-land agriculture in North Kohala, Hawai'i. American Antiquity 65(3):423-448.

LASS, BARBARA

1994 Hawaiian Adze Production and Distribution: Implications for the Development of Chiefdoms. University of California Institute of Archaeology Monograph 37. Los Angeles.

Lee, Georgia, and Edward Stasack

1999 Spirit of Place. Los Osos, California: Easter Island Foundation.

Malo, David

1951 Hawaiian Antiquities. B.P. Bishop Museum Special Publication 2. Honolulu: Bishop Museum. 
Maly, Kepā, and Helen Wong Smith

1999 Appendix B-1: A Report on Archival-Historical Documentary Research, Oral History Interviews and Assessment of Cultural Impacts, Prepared in Conjunction with the Environmental Impact Statement for the Proposed Màmalahoa Bypass. HWS 1250-g (022699). Hilo, Hawai'i: Kumu Pono Associates.

McCoy, Patrick C.

1977 The Mauna Kea adze quarry project: a summary of the 1975 field investigations. Journal of the Polynesian Society 86:223-224.

1990 Subsistence in a non-subsistence Alpine Desert environment: Natural and cultural factors of production in the Mauna Kea adze quarry industry, Hawai'i, in Pacific Production Systems: Approaches to Economic Prehistory, ed. D. Yen and J. M. Mummery. Research School of Pacific Studies, Australian National University.

Mills, Peter R., and Manije Irani

2000 A Walk Through History: Pedestrian Survey Along the Old Government Beach Road, Honalo to Honua'ino. Report Prepared for the State Division of Forestry and Wildlife, Na Ala Hele Program. Hilo: University of Hawai'i at Hilo.

National Park Service

1998 Ala Kahakai: National Trail Study and Final Environmental Impact Statement. San Francisco: National Park Service, Pacific West Region, Pacific Great Basin Support Office.

OCEANSIDE Partners

2000 The Old Government Beach Road. Ms. prepared by 1250 Oceanside Partners for the State Department of Land and Natural Resources. On File, Historic Preservation Division Office, Hilo.

REINECKE, J. E.

1930 Survey of Hawaiian Sites, 1929-1930. Unpublished manuscript Honolulu: Department of Anthropology, Bishop Museum.

Sahlins, Marshall

1992 Historical ethnography, in Anahulu: The Anthropology of History in the Kingdom of Hawai' $i$, vol. 1, ed. P. V. Kirch and M. Sahlins. Chicago: University of Chicago Press.

Sinton, John M., And Yosiniko H. Sinoto

1997 A geochemical database for Polynesian adze studies, in Prehistoric Long-Distance Interaction in Oceania: An Interdisciplinary Approach, pp. 194-204, ed. Marshall I. Weisler. New Zealand Archaeological Association Monograph 21. Auckland.

SOEHREN, Lloyd J.

1980a Archaeological and historical features on the parcel identified by Tax Map Key 7-9-05:8, situated at Honalo, North Kona, Hawai'i. Kilo 'Aina letter report, Hamilton Library, University of Hawai'i, Mānoa.

1980b Archaeological and historical features on the parcel identified by Tax Map Key 7-9$05: 16$, situated at Honalo, North Kona, Hawai'i. Kilo 'Aina letter report, Hamilton Library, University of Hawai'i, Mānoa.

STOKes, John, AND Tom Dye, EDs.

1991 Heiau of the Island of Hawai $i$ : A Historic Survey of Native Hawaiian Temple Sites. Honolulu: Bishop Museum Press.

Thurston, Lucy

1934 Lucy G. Thurston: Pioneer Missionary in Kona, Hawai i. Honolulu: The Friend.

Weisler, Marshall I.

$1990 a$ A technological, petrographic, and geochemical analysis of the Kapohaku adze quarry, Lana'i, Hawaiian Islands. New Zealand Journal of Archaeology 12:29-50.

$1990 \mathrm{~b}$ Sources and sourcing of volcanic glass in Hawai'i: Implications for exchange studies. Archaeology in Oceania $25: 16-25$.

WhitMan, JOHN B.

1979 An Account of the Sandwich Islands: The Hawaiian Journal of John B. Whitman 1813-1815. Honolulu: Topgallant Publishing Co.

WITHROW, BARBARA M.

1991 Prehistoric distribution of stone adzes on the island of Hawai'i: Implications for the development of Hawaiian chiefdoms. Asian Perspectives 29(2): 235-250. 


\begin{abstract}
A large network of coastal trails on Hawai' $\mathrm{i}$ Island was recently designated as a $\mathrm{Na}$ tional Historic Trail, but our understanding of the trail has been limited to historical documentation supported by scant archaeological data. The current study is based upon an archaeological survey of a 2-mile section of the trail in Kona where it crosses through a dozen ahupua 'a (traditional Hawaiian land divisions), and considers the significance of the coastal trail in relation to Hawaiian land use and exchange. Findings suggest that a trail paved with waterworn stones followed the same straight route as the current trail, which has been affected by numerous historical era modifications. Along with similar known examples in Kona, this finding calls into question a common assumption that all precontact and early historical Hawaiian coastal trails meandered along the contours of the coast. In addition to supporting chiefly endeavors such as the collection of tribute during the annual Makahiki festival, it is suggested that the straight trail may have supported regular exchange of domestic commodities across ahupua' $a$ boundaries in the prehistoric or premissionary eras, and broadens our anthropological perceptions of interdistrict exchange in relation to ahupua'a economics. KeYwords: Hawai' $i$, Kona, trails, Ahupua'a, exchange.
\end{abstract}

